\title{
Research on the Innovation of Industry-University-Research Institution Collaboration in China's Finance and Economics Universities
}

\author{
Wei Hongliang ${ }^{1}$, Chen Huihui ${ }^{2}$ \\ ${ }^{1}$ School of Finance, Nanjin University of Finance and Economics, Nanjing, China \\ ${ }^{2}$ Office of Innovation and Entrepreneurship and Achievement Transformation, Nanjing University, Nanjing, \\ China
}

Keywords: industry-university-research institution collaboration; finance and economics universities; policy analysis

\begin{abstract}
Industry-University-Research Institution Collaboration(IURC) is an important strategy for finance and economics colleges to achieve their talent training goals. At present, the IURC in China's financial and economic universities has just started, and there still exists many problems. To this end, this paper analyzes the problems that arise in the process of IURC in China's financial and economic colleges, and proposes solutions like refining the curriculum, deepen the teaching reform, strengthening the construction of the teaching staff, promoting the cultivation of students' practical ability, and strengthening the role of the government in the IURC.
\end{abstract}

\section{Introduction}

Industry-university-research institution collaboration (IURC) is a cooperation model between universities and enterprises. That is, with the help of the university's scientific research platform and the enterprise's practice platform, through the cooperation between the two sides, the universities will provide the consulting services and professional talents needed by the enterprises, in which way turning the educated talents into productive labor force, thus achieving mutual benefit.

The industry-university-research institution collaboration was first introduced in 1906 by Herman Schneider, Dean of the School of Engineering, University of Cincinnati. Since introduced, it has achieved rich achievements. Fred Teman, known as "Father of Silicon Valey", created "Silicon Valley Model" in the middle of the $20^{\text {th }}$ century, which leaded the IURC model into a new era. IURC started late in China, which was first introduced in the late 1980s. In 1997, the Ministry of Education promulgated the "Notice on Carrying out the $9^{\text {th }}$ "Five-Year" Pilot Work of IURC Education", and determined the pilot work of the IURC education in 28 colleges and universities across the country during the $9^{\text {th }}$ "Five-Year" period.

However, due to the long-standing misunderstanding of the IURC, China has been promoting the IURC mainly in higher vocational education, and failed to pay enough attention to the IURC in undergraduate colleges and universities. Until the National Science and Technology Conference in 2006, the positive role of the IURC in the process of achieving the goal of "the combination of theory and practice, equal emphasis on teaching and research, and the simultaneous development of talents and achievements” was widely recognized. After years of unremitting exploration, although the domestic IURC project has achieved some results, there is still a big gap compared with the advanced IURC model in Europe and the United States.

Domestic scholars have achieved fruitful results in the research on the IURC. In terms of the connotation, Deng Nianqing et al. (2000) believe that IURC is a multi-faced cooperation under the principle of sharing risks, complementing each other, mutual benefit and common development in the process of integration of science and technology and economy ${ }^{[3]}$. Lu Ming (2004) believes that IURC refers to the establishment of cooperative relations between universities and enterprises. Scientific research results obtained by research institutions and universities will be invested in enterprises to actively promote the transformation of scientific research results, and form a productive force in short ${ }^{4]}$. Liu $\mathrm{Li}$ (2005) believes that IURC is an exchange of knowledge between 
enterprises and research institutions ${ }^{[5]}$. In exploring the mode of IURC, Chinese scholars have also studied the classification and selection factors of the model. For example, Su Jingqin (1999) divides the IURC model into internalization mode, externalization mode and basis internalization mode from the perspective of transaction costs ${ }^{[6]}$. Wang Juanru et al. (2002) divided it into three categories, technical cooperation, contractual and integrated type, depending on the organizational rigor of the IURC ${ }^{[7]}$. Zhong Weijun (2009) divides the IURC model into four categories, cooperative technology innovation, cooperative talent training, cooperative use of advanced experimental equipment and instruments of colleges and universities and research institutions, and cooperation to obtain the information required, according to the differences in cooperation content ${ }^{[8]}$. Cui Xu (2010) divided the IURC model into joint development, commissioned development, joint construction of research and development institutions, joint construction of economic entities, and joint construction of talent training ground ${ }^{[9]}$. In addition, in the research on the education mechanism of IURC, Chen Jiefang (2006) proposed that the IURC and the combination of learning by doing ${ }^{[10]}$. Li Weiming (2011) divides the talent mechanism of IURC education into three levels: external, intermediate and core level. He proposes that the education of IURC must integrate the resources of universities and enterprises, and complement each other to effectively cultivate innovative talents ${ }^{[11]}$.

Domestic scholars have relatively deeply analyze the connotation and cooperation model of IURC, however, most research focus on higher vocational education and science and engineering education, few on finance and economics colleges and universities. Therefore, this paper, based on current status of IURC in domestic finance and economics colleges and universities, explores problems and deficiencies and puts forward corresponding policy suggestions and improvement measures.

\section{Problems in Current Industry-University-Research Institution Collaboration in Domestic Finance and Economics Colleges and Universities}

With the rapid development of China's economy, the trend of enterprise financialization is more prominent, and the demand for applied professional talents in finance and economics of enterprises is increasing. Various finance and economics colleges and universities have changed the direction of student training and expands the training scale of applied professionals. In this process, IURC has become the widely used student cultivation mode. It is noticeable that IURC in finance and economics universities is still in its infancy, and there are still many problems, mainly in the following aspect.

\subsection{The incomprehensive understanding of industry-university-research institution collaboration}

(1) More emphasis on theory than practice. Compared with science and engineering colleges and universities and higher vocational colleges, the practice of IURC in finance and economics colleges and universities are far more few. The theoretical results of science and engineering colleges and universities need to be realized by practice, which provides a good foundation for the development and implementation of the cooperation model of IURC. However, finance and economics colleges and universities, with application-oriented professionaltraining target, neglect students' practical teaching, which is mainly reflected in the curriculum arrangement, and the course time of the theoretical is significantly more than that of practical course. Although some institutions have begun to pay attention to practical teaching, they actually say more and do less. At the same time, the evaluation system of finance and economics colleges and universities also value theory more important than practice. For a long time, the reference standards for applying for master's and doctoral degrees in colleges and universities have mostly relied on scientific research results as the main support and evaluation basis, which leads to more emphasis on the ability and level of teachers' scientific research output when colleges and universities provide incentives for teachers, whereas, few on whether the research results are an armchair strategist or not, and whether the results can be transformed in to practice. More motivation of the scientific research carried out by 
teachers is to evaluate titles and take projects, thus the phenomenon of acting blindly is more, and the consideration of the scientific research carried out and the transformation of industrial demand is less.

(2) The inconsistent between training objective and enterprise demand. In the school-enterprise cooperation in enterprises, universities and research institutions, the training programs formulated by finance and economics universities are biased towards the "Jack of all trades and master of none”, which fails to accurately understand and grasp the real demands of enterprises. The common training mode is to instill a large amount of theoretical knowledge during the school, and to carry out some internship practice symbolically, and before graduation, carry out various job fairs and sell talents to enterprises. After the graduates enter enterprises, they often need a long time to adapt to work, which greatly reduces the production efficiency of enterprises. In the IURC model in developed countries, the school "develops the training plan according to the demand" ${ }^{[12]}$, namely according to the type of talents required by enterprises, to cultivate talents to meet market needs, that is, compound application talents with solid basic knowledge, professional work skills and practical management skills.

\subsection{The unequal benefits of school and enterprise}

As different interest entities, finance and economics universities and enterprises conduct IURC in talent training and project research, and both parties can obtain greater benefit through in-depth cooperation. For enterprises, finance and economics universities can provide professional talents and consulting services. For finance and economics universities, enterprises can provide relevant research fundings and alleviate the financial constraint of colleges and universities, and talent development programs signed with enterprises can also improve the employment of college graduates. However, the current actual situation is different. The attraction of IURC is not so attractive for schools. The main reason is that under the existing evaluation system, the evaluation of teacher title and school performance does not pay attention to the results produced by the IURC, and the complicated and difficult financial reimbursement procedures results in the smaller proportion of horizontal projects between schools and enterprises. On the other hand, the enterprise functions are positioned to maximize profits, and the pursuit of high-efficiency, low-cost, low-risk, and high-profit projects. As for the transformation of scientific research results, its long-term, high-cost, and high-risk characteristics discouraged enterprises. In addition, the current imperfect talent recruitment system in China has also led to the oversupply of talent market. Enterprises have the initiative, and they do not pay attention to the cultivation of talents. Therefore, their participation in IURC is not high.

\subsection{The imperfect system construction}

For a long time, China's IURC construction has mainly focused on science and engineering colleges and universities and related enterprises, and there is a lack of policy support and institutional guarantee for cooperation between financial institutions and enterprises. IURC is the most effective way to achieve the three basic functions of scientific research, personnel training and social services in finance and economics institutions, but the current rules and regulations cannot meet and fulfill most of the financial and economic institutions to achieve such goals. Finance and economics colleges and universities with professional talents in finance and economics as the training target are different from science and engineering colleges that focus on technological innovation, so that the acquired IURC system and model of science and engineering colleges cannot be applied to financial and economic institutions. Finance and economics colleges and universities urgently need a set of IURC system to guide them to complete the establishment of disciplines, the evaluation of scientific research results and the reasonable arrangement of expert resources, so as to realize the three basic functions of scientific research, education and service. At the same time, the role of the government has not been played in the IURC between financial institutions and enterprises. The cooperation between schools and enterprises is mostly the direct cooperation between the two, rarely through the government platform. Cooperation is only promoted by projects, which leads to the interruption of cooperation between enterprises and schools after the completion 
of the project, which cannot achieve the intention of building long-term deep strategic cooperation. This short-cycle and unsustainable cooperation is not a true IURC.

\section{Suggestions on Model Innovation of Industry-University-Research Institution Collaboration in Domestic Finance and Economics Universities}

Promoting the development of IURC in finance and economics colleges and universities depends not only on the changes made by the schools themselves, but also on the joint efforts of enterprises, governments and higher institutions, to truly forms a four-in-one cooperation model of government, industry, university and research, with government as dominance, enterprise as stage and universities as the mainstay. Therefore, this paper proposes policy recommendations.

\subsection{To detail curriculum and deepen teaching reform}

Training professional talents in finance and economics is the goal of applied finance and economics institutions. The goals of talent cultivation is closely related to the curriculum setting. The cultivation of applied talents should emphasize "accuracy" rather than "widespread" in curriculum setting, highlight the key courses, and carefully arrange the courses with typical professional characteristics from the class hour setting, teaching content, and teaching methods. When setting up professional courses, it is necessary to closely follow the development of the industry, pay close attention to the research frontiers and hotspots of the industry, and focus on practical application, in line with reality, to stay in close contact with the actual course, which can reduce the discomfort of students in the job. At the same time, the post teaching of professional courses should be equipped with a double tutor system. The in-school and out-school tutor should work together to construct the specialized knowledge system, and train students' practical ability in enterprises to realize the seamless connection between school and enterprises.

At the same time, financial and economic universities should also renew the teaching methods. In traditional teaching modes, teachers grasp the dominance of the class, and students usually feels drowsy. The enthusiasm of students in the classroom should be mobilized through "brainstorming", "leaderless group discussion", "heuristic teaching", etc. Students should take control of the initiative of the classroom, while the teacher provide proper guidance and comments. At the same time, teachers should strengthen the proportion of case teaching. Case teaching method is to combine professional theoretical knowledge with actual situation. Teachers should select typical representative, practical and cutting-edge cases to guide students to think and discuss and improve students' ability to combine theory with practice.

\subsection{To strengthen the construction of teaching staff, and promote the cultivation of students' practical ability}

An excellent teaching staff is a prerequisite for building a high-level institution. To promote the development of IURC, it is necessary to build a teaching team of IURC with rich practical experience, with not only a solid theoretical foundation, but also strong practical ability. From bachelor to master degree, from master degree to doctor degree, from doctor degree to college teachers, this is the learning experience of most teachers in financial and economic colleges. Most of them do not have the experience and background of the practice. In order to cultivate applied talents that meet the needs of the industry, excellent compound teachers are the premise and guarantee. The school can enhance the professional practice ability of the teaching team by the two methods. First, to cooperate with enterprises, arrange teachers to go to the professional counterpart enterprises to work and accumulate practical experience; Secondly, to introduce talents and hire senior executives with rich professional practice ability as external teachers to make full use of their rich practical knowledge to fill the shortcomings of the school's talent training. In addition, schools should improve the incentive mechanism and methods for teachers' scientific research and teaching, strengthen the proportion of the results of IURC in the evaluation of ranks and performances; guide teachers to pay attention to the transformation of scientific research results through the immediate interests; partially change the financial reimbursement system of horizontal projects, encourage 
teachers to apply for horizontal projects, provide consulting services for enterprises, and give play to the functions of social services in colleges and universities.

The key to the cooperation between industry, university and research is the cultivation of students' practical ability. The financial and economic laboratories, the multi-party scientific and technological parks, the off-campus research and practice bases, and the research and innovation centers jointly established by colleges and universities and enterprises are all important platforms for the cooperation between schools and enterprises to conduct IURC. Through these platforms, colleges and universities can establish long-term sustainable partnerships with enterprises, ensure the long-term IURC, and promote the development of an educational economy and society.

\subsection{To strengthen the role of government in industry-university-research institution collaboration}

In the current stage of the cooperation between industry, university and research institutes, the government should undertakes the role and responsibility as a leader. For colleges and universities, the government education department must reform the current teaching evaluation and talent incentive system. In the evaluation system of financial and economic colleges, it is necessary to introduce the evaluation index of IURC and practical teaching, and establishes a set of education evaluation system that meets the characteristics of financial institutions. In this way, the decision-makers of colleges and universities will attach importance to the cooperation of industry, university and research, and teachers will have the motivation to participate in practical teaching and cooperation in industry, university and research. At the same time, the government departments should set up special agencies to eliminate the information asymmetry between higher institutions and enterprises and coordinate the interests between them in accordance with the local economic development and the characteristics of the school and enterprise. For projects with unequal benefits, especially those that benefit colleges and universities and increase the spending of enterprises, the government should provide tax preference and financial assistance. In the IURC, the government should carry out reasonable and careful industrial planning, and clarify the industrial priorities, practices and promotion measures of each period. The government must become the organizer and promoter of the IURC, and become the commander and participant.

\section{Acknowledgement}

Fund project: The phased results of school-level project of teaching reform in 2011-2012 academic year of Nanjing University of Finance \& Economics, "Research and Practice of Industry-University-Research Integration and Off-campus Practical Base Construction in School of Economics and Finance”, Project Grant No. JGY1223; the phased results of 2013 project of Jiangsu Province Education Science $12^{\text {th }}$ "Five-Year" plan (fund by higher education), "Study on Research-based Teaching of Finance Majors in Finance and Economics Colleges and Universities in China”, Project Grant No. B-a/2013/01/008; the phased results of Jiangsu Education Department "Phase IA-Type Project of Brand Specialty Construction Project of Jiangsu Colleges and Universities”, Project Grant No. PPZY2015A001.

\section{References}

[1] Mo Shannong. Study on Talent Development in Universities of Finance and Economics Based on the Mode of "Industry-University-Institute" Cooperation [J]. Journal of Guangxi University of Finance and Economics, 2014, 27(1):120-124.

[2] Yu Lan, Wang Li. Research on Industry-university-research institution collaboration in Finance and Economics Colleges and Universities [J]. Guizhou Social Sciences, 2011(12):96-98.

[3] Deng Nianqing, Bian Xiufan. On Industry-university-research institution collaboration in Colleges and Universities in New Trend [J]. Journal of Anhui Agricultural University (Social Science Edition), 2000(1):63-64. 
[4] Lu Ming. The Only Way for Universities to Keep Sustainable Development: Technology Innovation and Industry- University-Research Cooperation [J]. Jounal of Wuhan University of Technology (Information\& Management Engineering), 2004, 26(4):121-123.

[5] Liu Li. Transaction Cost and Dynamic Mechanism of Industry- University-Research Cooperation -Analysis of New Institutional Economics [J]. Forum on Contemporary Education, 2005(3):15-17.

[6] Su Jingqin. Innovation Cooperation between Industry, University and Research Institutes: its Transaction Cost, Internalized and Externalized Conditions [J]. Science Research Management, 1999, 20(5):68-72.

[7] Wang Juanru, Pan Jieyi. A Discuss on Production, Academic Studies and Research Institution Cooperation Model [J]. Scientific Management Research, 2002, 20(1):25-27.

[8] Zhong Weijun, Mei Shu'e, Xie Yuanyuan. Analysis of Technological Innovation Modes for the Industry-University-Institute Cooperation [J]. China Soft Science, 2009(8):174-181.

[9] Cui Xu, Xing Li. Cooperation Models of Industry-University-Research and Conditional Factors in China: in Three Angles of Government, Industry, University [J]. Science and Technology Management Research, 2010, 30(6):45-47.

[10] Chen Jiefang. On "Industry-university-research institution collaboration” and "Combination of Learning with Working” [J]. Mechanical Vocatonal Education, 2007(4):34-36.

[11] Li Weiming, Li Chunyan. Study on Cultivation Mechanism of Innovative Talents in Colleges and Universities under the Industry-university-research institution collaboration Mode [J]. The Road to Success, 2015, 8.

[12] Zhou Ling, Yang Wenyou. Study on Problems and Measures of Industry-university-research institution collaboration in Finance and Economics Colleges and Universities [J]. Journal of Nanjing Audit University, 2008, 5(3):108-110. 